3. Voziyan, V.I. Pitatelnaya tsennost sortov soi, goroha, fasoli i soderzhanie v nih antipitatelnyih veschestv / V.I. Voziyan, M.G. Taran, M.D. Yakobutsa, L.P. Avadeniy «Zernobobovyie i krupyanyie kulturyi». - \#1(5) - 2013. - S.26-29

4. Kosolapov V. M. Rol kormovih zernobobovih kultur v ukreplenii kormovoy bazyi zhivotnovodstva / V. M. Kosolapov I. A. Trofimov «Zernobobovyie i krupyanyie kulturyi», \# 1, $2012 \mathrm{~g}$ S 98-101

5. E. Koivunen, Digestibility and energy value of pea (Pisum sativum L.), faba bean (Vicia faba L.) and blue lupin (narrowleaf) (Lupinus angustifolius) seeds in broilers / E. Koivunen, K. Partanen, S. Perttilä, S. Palander, P. Tuunainen, J. Valaja // Animal Feed Science and Technology, Volume 218, 2016, Pages 120-127

6. Field Pea Grain and Forage for Beef Cattle. Електронний ресурс. - Режим доступу https://www.ag.ndsu.edu/publications/livestock/field-pea-grain-and-forage-for-beef-cattlelas1301.pdf

7. Acidosis in cattle a revive / F.N. Owens, D.S. Secrit, W.J. Hill, D.R. Gill // Journal of Animal Science. - 1998. - V 1. - P 275-286.

8. Waste_to_worth_vegetable_wastes_as_animal_feed. Електронний pecypc. - Режим доступу https://www.researchgate.net/profile/Mohinder_Bakshi/publication/306395604_Waste_to_worth_vegetable_wastes_as_ani mal_feed/links/57bcb21908aedf5f75eaa $45 d /$ Waste-to-worth-vegetable-wastes-as-animal-feed.pdf

9. Stranyi Prichernomorya vyitesnyayut «starozhilov»s ryinka bobovyih kultur. Elektronniy resurs. - Rezhim dostupu http://www.ukragroconsult.com/news/strany-prichernomorya-vytesnyayut-starozhilov-s-rynka-bobovyh-kultur

10. Metodychni vkazivky do vykonannia laboratornykh robit z kursu «Naukovo-tekhnichnyi prohres u zernopererobnii haluzi» (kombikormova haluz). - Ch.1. - Odesa. - 47 s.

11. Levytskyi A. P. Deklaratsiinyi patent na korysnu model № 31012. Sposib modeliuvannia dysbiozu (dysbakteriozu) / A. P. Levytskyi, I. O. Selivanska, Yu. V. Tsiselskyi [ta in.] - № u 200711609; zaiavl. 22.10.2007; opubl. 25.03.2008. Biul. № 6.

12. Levytskyi A.P. Biolohichnyi metod vyznachennia prebiotychnykh vlastyvostei produktiv funktsionalnoho pryznachennia $/$ A.P. Levytskyi, V.T. Hulavskyi, I.O. Selivanska // Naukovi pratsi ONAKhT. - 2012. - vyp. 42.t.1. - S. 194-197.

13. Nertila Malushi Determination of chemical content and dru matter digestibility of some under-utilized feeds in ruminant feeding through two in vitro metods / Nertila Malushi, Lumturi Papa , Margarida Mai, Hugo Oliver // Animal Science. Vol. $L X, 2017$. - P.91-96.

14. Lazarevich A.N. Soloma v ratsionah selskohozyaystvennyih zhivotnyih: rekomendatsii / A.N. Lazarevich, A.P. Lesnov; FGBNU Krasnoyarskiy NIIZh. - Krasnoyarsk, 2016. - 90 s.

15. Jane Wamatu Nutritive value of field pea (Pisum sativum L.) straw as influenced by variety, season, botanical fractions and urea pretreatment / Jane Wamatu, Ashraf Alkhtib, Dawit Abate, Seid Ahmed Kemal, Barbara Rischkowsky // Animal Feed Science and Technology. - Volume 225. - 2017. - P. 54-61. ISSN 0377-8401.

16. Pablo Gregorini Screening for diets that reduce urinary nitrogen excretion and methane emissions while maintaining or increasing production by dairy cows / Pablo Gregorini, Pierre C. Beukes, Dawn Dalley, Alvaro J. Romera // Science of the Total Environment. - 2016. P.- 32-41.

17. Biohimicheskie markeryi vospaleniya tkaney rotovoy polosti: metod. rekomendatsii / A.P. Levitskiy, O.V. Denga, O.A. Makarenko [i dr.].- Odessa, 2010. - 16 s.

18. Fermentativnyiy metod opredeleniya disbioza polosti rta dlya skrininga pro- i prebiotikov: metod. rekomendatsii / A. P. Levitskiy, O. A. Makarenko, I.A. Selivanskaya [i dr.]. - K.: GFTs, 2007. - 26 s.

Надійшла 07.05.2018. До друку 17.05.2018

Адреса для переписки

вул. Канатна, 112, м. Одеса, 65039

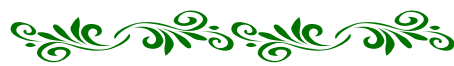

\title{
ОСОБЛИВОСТІ КОНСТРУКЦІЇ І ЗАСТОСУВАННЯ ФОТОЕЛЕКТРОННОГО ОБЛАДНАННЯ АЛЯ РОЗДІ- ЛЕННЯ ЗЕРНА I ЗЕРНОПРОДУКТІВ НА ФРАКЦІЇ ЗА ОЗНАКОЮ КОЛЬОРУ
}

\footnotetext{
Анотація

Фотоелектронне сепарування застосовують для сортування різноманітних сипких продуктів, у тому числі - зерна і деяких продуктів його переробки.

Фотоелектронні сепаратори використовують для очищення зерна від важковідділюваних домішок, які досить складно або навіть неможливо відокремити з допомогою звичайних зерноочисних сепараторів. Окрім того, їх застосування доиільне для розділення на фракиії основних продуктів лущення зерна круп'яних культур.

Фотоелектронне, або оптичне сепарування базується на ідентифікації частинок сипких продуктів як за ознакою кольору, так і їх форми і текстури. Для иього використовують оптичні камери. Електронні блоки обробки отриманої графічної інформачії передають ї̈ в пневматичні пристрої ежекторного типу для виведення домішок із основного потоку продукту. Оптичні датчики і повітряні ежектори функиіонують у безконтактному режимі, що повністю узгоджуються з вимогами гігієнічності харчових технологій. До того ж вони є швидкодіючими, щьо забезпечує високу продуктивність сепарування. Ефективність вилучення домішок сягає 80...99,99\%. Довговічність фотоелектронних сепараторів характеризують числом цииклів $N_{u}$ спрацювання пневматичних клапанів ежекторів. Більшість фірм гарантує $N_{u} \geq 50$ млн циилів.
} 
На ринку обладнання знайтли потирення фотоелектронні сепаратори «Зоркий» російської компанії «СиСорт» продуктивністю $5 . .15$ m/год, англійські сепаратори фірми «Sоrtex», сепаратори китайської фірми ANYSORT i деякі інщі.

Впровадження фотоелектронних сепараторів у виробництво може призвести до оптимізаиї технологічних процесів і потокових ліній для їх реалізації, а також до підвищення конкурентоспроможності виробленої продукиї̈ на внутрішньому і зовнішньому ринках.

Ключові слова: фотоелектронний сепаратор, оптичне сепарування, сепарування за ознакою кольору, оптична система, оптичне сортування, інспекційна система, ежекторне вилучення домішок, фотоелектронні сепаратори модельного ряду «Зоркий», фотосепаратори «Sоrtех», фотоелектронний сепаратор СРФ-5,0.

Фотоелектронні сепаратори застосовують для сортування різноманітних сипких продуктів: плодів, овочів, горіхів, кави, бобових, насіння, зерна і деяких продуктів його переробки. На підприємствах галузі фотоелектронні сепаратори використовують для вторинного очищення зерна від важковідділюваних домішок, які досить складно або навіть неможливо відокремити 3 допомогою звичайних зерноочисних сепараторів. Це може бути насіння смітних рослин - вівсюга, кукіля, татарської гречечки; зернівки, зіпсовані самозігріванням і сушінням, мікроорганізмами, уражені головнею і ріжками, рожевозабарвлені, пожовтілі, знебарвлені та інш. Окрім того, їх застосування доцільне також для вилучення нелущеного зерна із основних продуктів лущення зерна круп'яних культур, для сортування зерна рису, вівса, пшениці, кукурудзи, ячменю, сої, гороху на різних етапах круп'яного виробництва.

Фотоелектронне, або оптичне, сепарування базується на ідентифікації частинок сипких продуктів не тільки за ознакою кольору, але й їх форми i текстури. Для цього використовують оптичні камери. Електронні блоки обробки отриманої графічної інформації передають іiі в пневматичні пристрої ежекторного типу для виведення домішок із основного потоку продукту. Оптичне сепарування повністю узгоджується з вимогами гігієнічності харчових технологій, оскільки оптичні датчики і повітряні ежектори функціонують у безконтактному режимі. До того ж вони є швидкодіючими, що забезпечує високу продуктивність сепарування. Ефективність вилучення домішок сягає 80...99,99\%. Довговічність фотоелектронних сепараторів характеризують числом циклів $N_{u}$ спрацювання пневматичних клапанів ежекторів. Більшість фірм гарантує $N_{u} \geq 500$ млн циклів.

Фотоелектронний сепаратор «Зоркий» російської компанії «СиСорт» зображено на рис. 1, 3 якого походить, що сепаратор вміщує приймальнорозподільний пристрій 1 , лоток 3 каналами 2 , фотоелектронний блок 3 пневматичною системою вилучення домішок, станину 4 і дисплей 5 для контролю i управління. Принцип дії фотоелектронних сепараторів пояснює узагальнена функціональна схема на рис. 2 .

Приймально-розподільний пристрій для початкової зернової суміші (1) складається з приймального бункера і вібролотків 1, кількість яких залежить від продуктивності сепаратора і змінюється від одного до трьох, хоча слід зазначити, що високопродуктивні сепаратори деяких фірм мають 4, 7 і навіть 10 лотків-живильників.

Безпосередньо під вібролотками знаходяться похилі нерухомі лотки 2 з каналами, по яких частинки продукту рухаються самопливом, рівномірноприскорено, у вигляді ланцюжка. Для зменшення коефіцієнта тертя продукту по поверхні каналів, деякі фірми покривають їх спеціальними антифрикційними матеріалами, наприклад, фторопластом 4. На сході з каналів швидкість потоку продукту дорівнює $4 \ldots 5$ м/c. Він потрапляє в зону дії блоків 3 і 4 оптичної інспекції у вигляді однорідної, досить розрідженої рівномірно розподіленої стрічки, без грудок і взаємного перекриття частинок, бо інакше і нормальний продукт може бути вилучений з зони інспекції разом 3 частинками домішок.

Лампи 5 освітлюють зону інспекції, оптичні камери 6 сканують частинки продукту на фоні панелей 7 і передають графічну інформацію на електронні блоки обробки 8. Блоки іiі аналізують i, у разі виявлення домішок, надсилають керівні сигнали на клапани ежектора. Частинка домішки, пролітаючи повз сопла ежектора, отримує імпульс від повітряного струменя, спрямованого на частинку у відповідний момент часу, відхиляється від нормальної траєкторії вільного падіння, потрапляе в окремий збірновивідний лоток і крізь патрубок 11 виходить назовні за напрямком (3). Нормальні частинки не викликають спрацювання пневмоклапанів і безперешкодно вилучаються потоком (2) крізь патрубок 10.

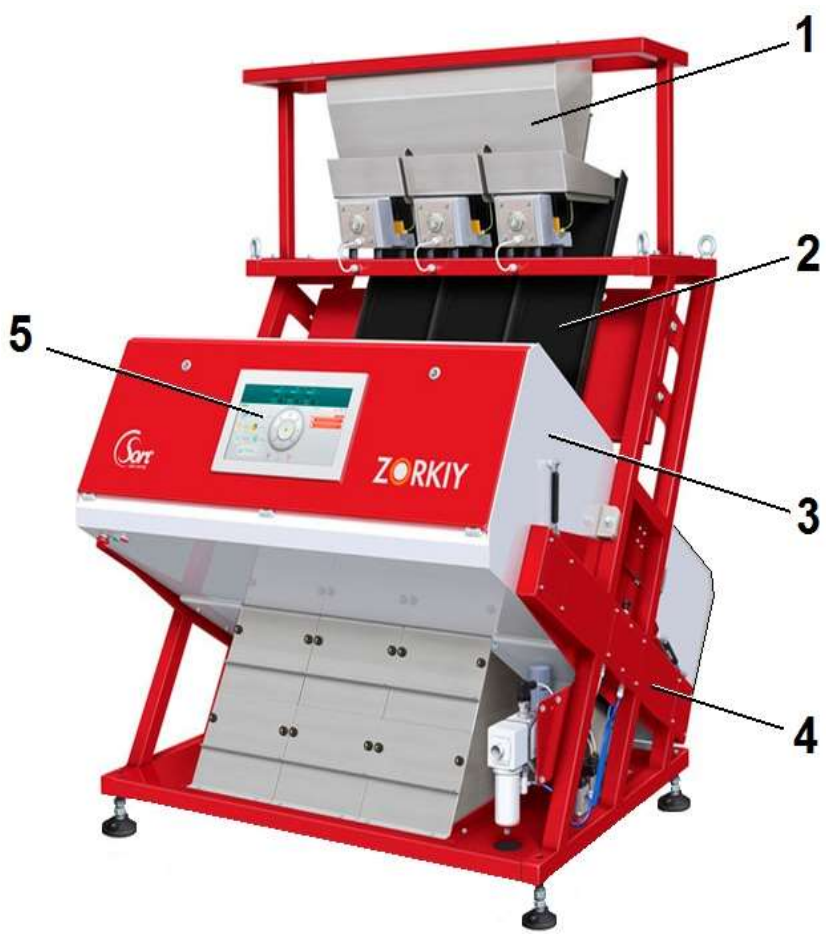

Рис. 1. Загальний вигляд фотоелектронного сепаратора Зоркий:

1 - приймально-розподільний пристрій; 2 - лоток 3 каналами; 3 - фотоелектронний блок 3 пневматичною системою вилучення домішок; 4 - станина;

5 - дисплей для контролю і управління 
У якості джерел освітлення зони інспекції застосовують лампи розжарювання, люмінесцентні, металогалагенні, світлодіоди і лазери, узяті окремо або в певнім сполученні.

Перевага перевірки продукту у стані вільного польоту полягає в тім, що його можна перевіряти 3 обох боків. Схема (рис. 2) показує оптичну систему з камерами, які розглядають продукт як 3 передньої (фронтальної, або верхньої) сторони, так і з задньої (нижньої). Оптична система розміщується в оптичних боксах з камерами і освітленням, розташованим за загартованим склом. Потік продукту не контактує 3 оптичними вікнами, які періодично очищуються допоміжною автоматичною системою.

Мета оптичної системи - захоплення одного або декількох зображень кожної частинки у потоці i забезпечення правильності ії відображення без змінення освітлення, затінення і перекривання. Ці зображення передаються у процесор зображень, який визначає місцезнаходження дефектів на отриманих зображеннях і надсилає цю інформацію у систему вилучення домішок.

Оптичне сортування здійснюють інспекційні системи, які захоплюють зображення з застосуванням одного або декількох фільтрів світлового спектра - інфрачервоні і ультрафіолетові довжини хвиль у тому числі. Оптична система, як правило, характеризується довжиною хвилі світла, до якого вона чутлива. Продукт, звичайно, розглядають на фоні певного кольору, наприклад, білого. Застосовують камери лінійного сканування, які захоплюють зображення шляхом об'єднання послідовних одиничних лінійних зображень частинок продукту.

Роль системи вилучення полягає в тім, щоб відокремити небажані частинки (домішки, зіпсовані частинки і т. ін.) від основного продукту. Зазвичай, це відбувається під час польоту частинок: кондиційний продукт продовжує свій рух за нормальною траєкторією, а усі інші частинки, під впливом короткого струменя стисненого повітря з ежектора, відхиляються вбік і потрапляють у окремий збірник. Для цього необхідно забезпечити точне наведення ежектора на відповідну частинку, щоб мінімізувати втрати основного продукту з вилученими домішками. Конструктивно це вирішується шляхом з'єднання ежектора 3 високошвидкісним соленоїдом або п'єзоелектричним клапаном. Пневматичні клапани ежекторів повинні бути швидкодіючими, надійними і мати достатню механічну міцність. Наприклад, тривалість імпульсу стисненого повітря, яку забезпечує п'єзоелектричний клапан англійської фірми Sortex, дорівнює $(0,8 \ldots 1) 10^{-3} c$. Число циклів спрацювання пневмоклапанів повинно бути не менш за один мільярд. Відтак, особливу увагу приділяють якості застосованого технологічного повітря. Регламентують вміст в очищеному повітрі пилу, вологи і мастила. Система підготовки повітря вміщує окрім компресора (бажано, безмасляного), ресивер, осушувач рефрижераторного типу, фільтри грубої, середньої і тонкої очистки.

Як правило, точка вилучення знаходиться поза межами зони оптичної інспекції, оскільки дію повітряного струменя може створити проліт частинок

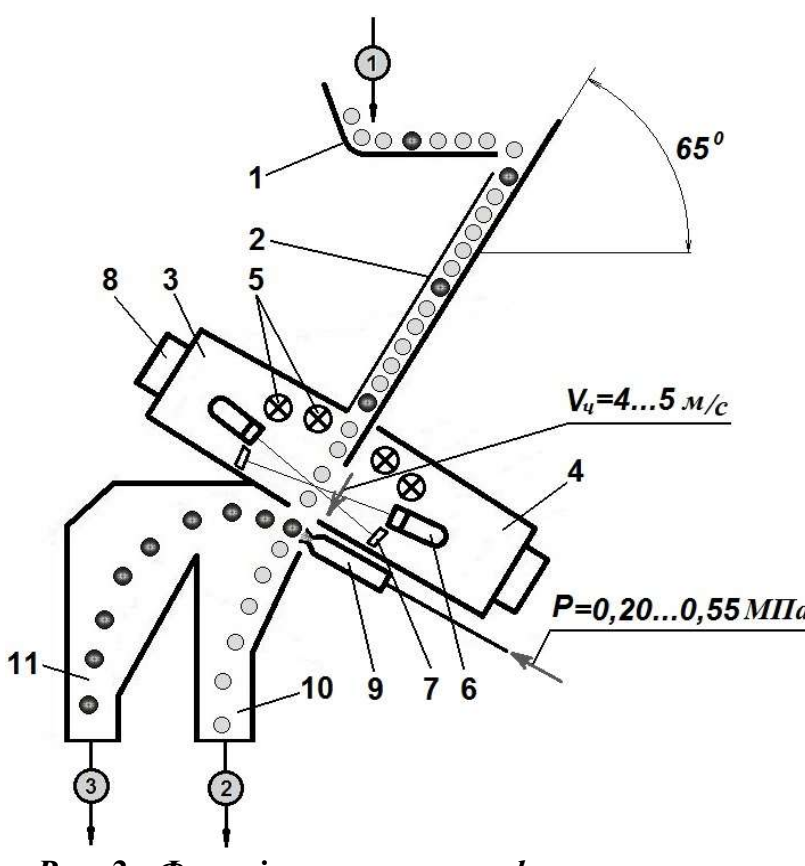

Рис. 2 - Функціональна схема фотоелектронного cenapamopa:

1 - вібролотковий живильник; 2- багатоканальний лоток самопливного типу; 3, 4-верхній (фронтальний) $і$ нижній (задній) блоки оптичної інспекиії; 5-лампи освітлення зони

інспекиї̈; 6-оптична камера; 7 - панель з кольоровим фоном; 8 - електронний блок обробки графічної інформаиії; 9 - блок ежекторів; 10, 11 - патрубки випускні для очищеного зерна і відходів; (1) - початкова зернова суміш; (2) - очищене зерно; (3) - відходи

пилу або залишків оболонок і спровокувати псевдовідмови. Однак, неминучі змінення у траєкторії кожної окремої частинки примушують розробників сепараторів здійснювати вилучення домішок якнайшвидше після закінчення оптичної інспекції. Електронна схема забезпечує певну затримку у часі між проходженням зони інспекції і точки вилучення. Точне визначення цієї затримки необхідно для співпадіння початку подачі повітряного струменя ежектором 3 моментом входження частинки в зону вилучення. Чим більше ця відстань, тим важче прогнозувати траєкторію кожної частинки продукту. Досвід показує, що час перебування частинок в зоні дії ежектора дорівнює $1,4 \cdot 10^{-3} c$, що майже вдвічі більше за тривалість імпульсу повітряного струму. Теоретично це повністю виключає можливість його потрапляння на іншу зернівку, не відбраковану оптичною системою. Тому час спрацювання електронної і пневматичної систем необхідно чітко скоординувати 3 відстанню від місця виявлення домішки оптичною системою до робочої точки ежектора, а також зі швидкістю вільного падіння зернівки на цій дільниці.

Механізм системи вилучення складається 3 масиву ежекторів, розташованих пліч-о-пліч по ширині машини, і двох окремих збірників - для основного продукту і домішок. Кожний ежектор може бути включено окремо, незалежно від інших, для подачі короткого імпульсу стисненого повітря крізь сопло діаметром близько 5 мм. Для невеликих об'єктів, таких як зернівки, імпульсу одного або двох сусідніх ежекторів достатньо для вилучення однієї частинки. 


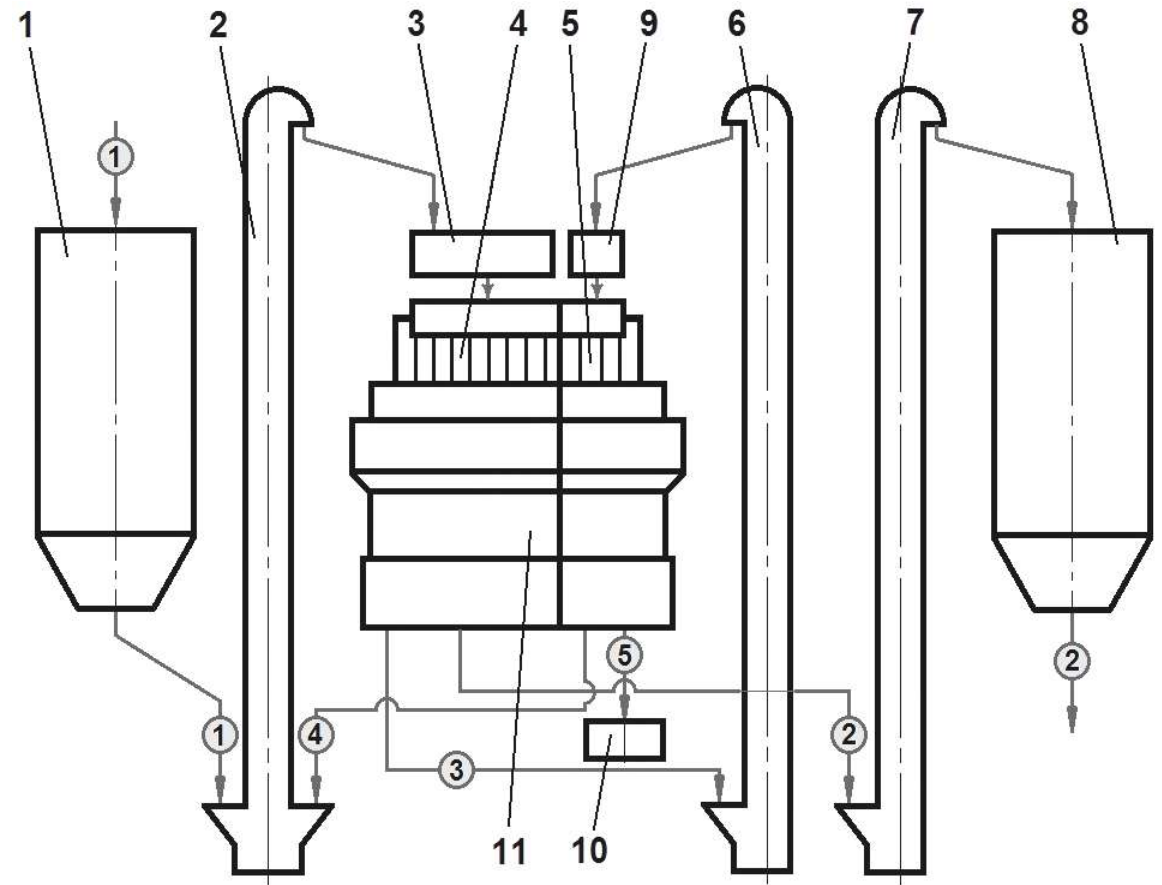

Рис. 3. Схема ділянки зерноочисної потокової лінії 3 фотоелектронним сепаратором:

1 - бункер для початкової зерносуміші; 2, 6, 7 норія; 3 - бункер для подачі зерносуміші у робоче відділення 4 фотоелектронного сепаратора $11 ; 5$ - контрольне відділення фотоелектронного сепаратора; 8 - бункер для очищеного зерна; 9 - бункер для подачі від-ходів робочого відділення у контрольне;

10 - бункер для відходів; (1) - початкова зернова суміш;

(2) - очищене зерно; (3) - відходи робочого відділення; (4) - проміжна зернова суміш, очищена від домішок у контрольному відділенні сепаратора;

$$
\text { (5) - відходи }
$$

Оскільки основна мета сепарування це максимальне очищення основного продукту від небажаних частинок, то при ефективності вилучення домішок на рівні 90...99\% вміст нормального зерна у складі вилучених домішок може дорівнювати $70 \ldots 80 \%$ від їх маси. Тому застосування фотоелектронних сепараторів передбачає необхідність і можливість контрольної обробки вилучених відходів. Для цього лотки з каналами підрозділяють на робочі $\mathrm{i}$ контрольні (до $10 \ldots 20 \%$ загальної кількості). Схема включення фотоелектронного сепаратора у склад обладнання зерноочисної потокової лінії наведена на рис.3.

Початкова зернова суміш (1) надходить в бункер 1, звідки норією 2 подається в бункер 3, розташований над робочим відділенням 4 фотоелектронного сепаратора 11. Очищене зерно (2) 3 робочого відділення норією 7 завантажується в бункер 8.

Відходи робочого відділення (3), які іноді вміщують до 80\% нормального зерна, норією 6 подаються у бункер 9 над контрольним відділенням 5, де продовжується вилучення домішок, які у вигляді відходів (5) надходять у бункер 10. Проміжна зернова суміш (4), що створюється у контрольному відділенні, потрапляє в норію 2, яка спрямовує їі разом 3 початковим продуктом (1) у робоче відділення для повторного проходження процесу оптичного сепарування.

Очевидно, що в залежності від місцевих потреб і особливостей потокових ліній підприємств, мо- жливі інші варіанти використання фотоелектронних сепараторів. Наприклад, високопродуктивні потокові лінії можуть застосовувати групу 3 декількох машин у режимі робочих, а один у якості контрольного для обробки відходів цієї групи.

Модельний ряд фотоелектронних сепараторів «Зоркий» дозволяє підібрати продуктивність у інтервалі від 50 кг до $15 \mathrm{~m} /$ год. Для цього слугує універсальна рамна конструкція, яка передбачає, у разі необхідності, збільшення продуктивності шляхом встановлення додаткових секцій (рис.4) .

Фотоелектронний сепаратор СРФ-5,0 виробничого об'єднання «Пролетарский завод» (м.Санкт-Петербург, РФ) розробили на основі англійських сепараторів фірми "Sortex".

Призначення, принцип дії і конструкція сепараторів СРФ, в загальних рисах, співпадають 3 описаними вище. Вони вміщують приймальнорозподільний пристрій, фотоелектронний блок ідентифікації частинок продукту за ознакою кольору, пневматичний пристрій для вилучення домішок і збірно-вивідні воронки для продуктів сепарування.

Приймально-розподільний пристрій складається $з$ приймального бункера, вібролоткового живильника-розподільника і нерухомих похилих (під кутом у $65^{0}$ до горизонту) лотків 3 каналами шириною 10 мм і довжиною 800 мм. Рухаючись по цих каналах, частинки продукту набувають швидкість $4,5 \ldots 5 \mathrm{M} / \mathrm{c}, 3$ якою потрапляють у фотоелектронну зону інспекції, де відбувається їх ідентифікація в залежності від кольору.

Фотоелектронний вузол виявлення дефектних зернівок складається з електронної системи формування опорного сигналу на базі рідкокристалічної пластини, багатоелементного фотоприймача (фотоелемента) і підсилювача сигналу. Якщо фотоелемент не помічає різницю у кольорі частинки і фону, то він лишається у режимі спокійної роботи. При появі зернівки, колір якої відрізняється від еталона, фотоелемент подає сигнал на електронний блок, який його підсилює і передає на пневматичний вузол ежекторного типу системи вилучення домішок.

Короткі імпульси повітряних струменів від ежекторів примушують частинки домішок змінити їх траєкторію для вилучення крізь окремий збірник, тоді як основний продукт продовжує безперешкодний рух в збірно-вивідний пристрій для очищеного зерна. 

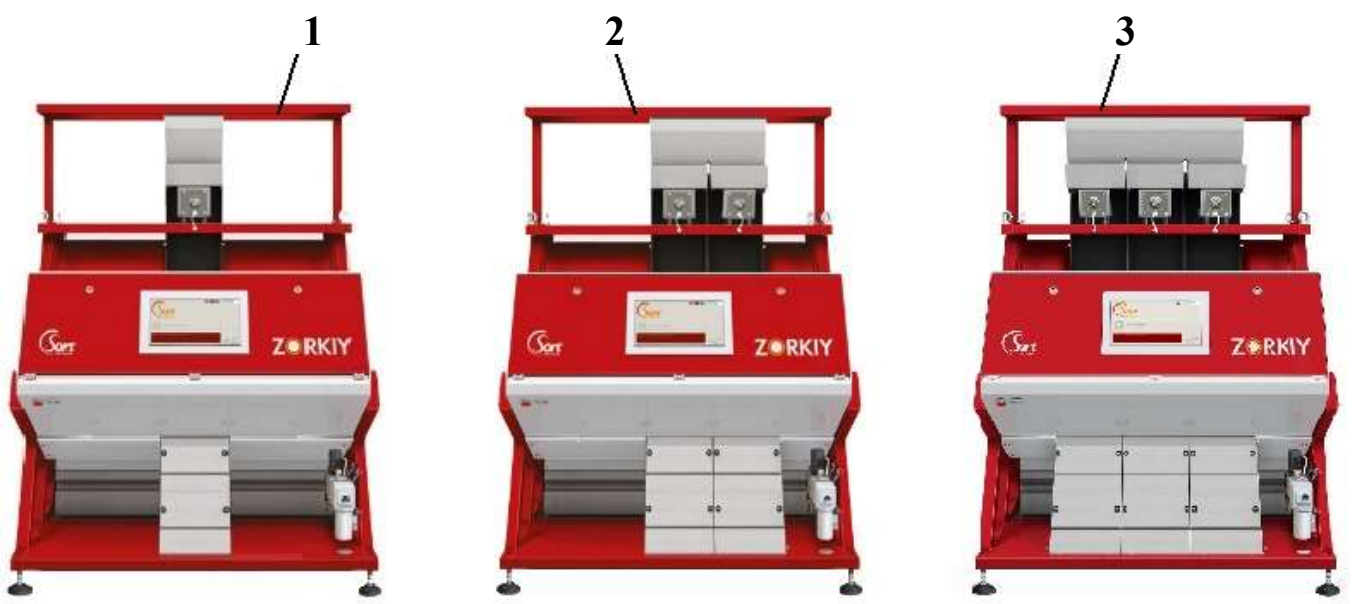

Рис. 4. Модельний ряд фотоелектронних сепараторів "Зоркий": 1 - односекційний; 2 - двосекційний; 3 - трисекційний

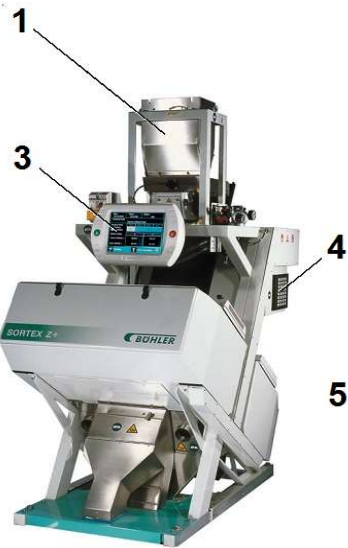

a)

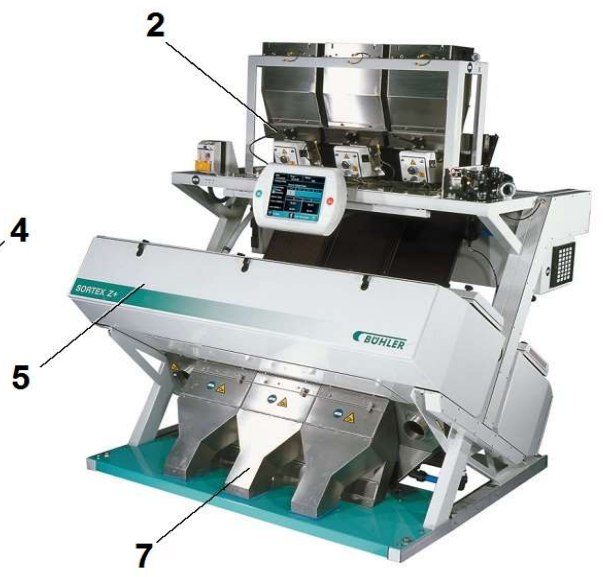

б)

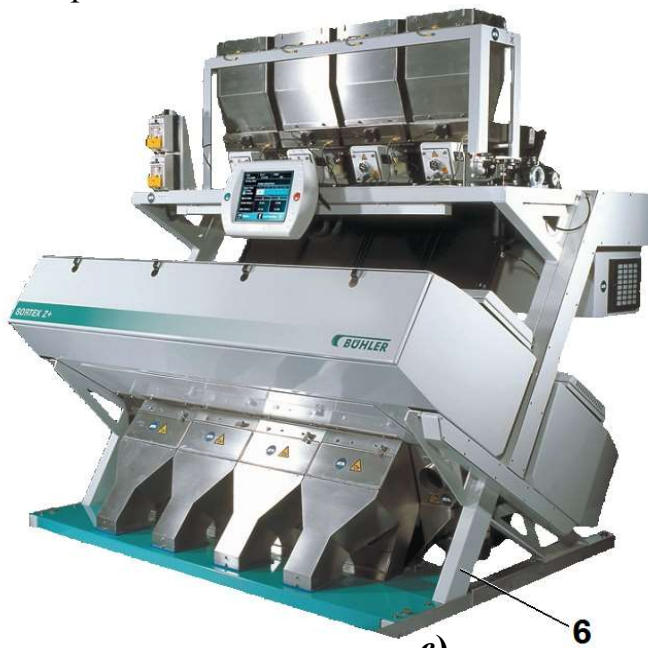

в)

Рис. 5. Фотоелектронні сепаратори типорозмірного ряду "Сортекс":

$\boldsymbol{a}$ - однолот-ковий; $\sigma$ - трилотковий; в - чотирилотковий; 1 - приймальний бункер; 2 - вібролотковий живильник-розподільник; 3 - дисплей; 4 - панель керування; 5 - корпус; 6 - станина; 7 - патрубок випускний

Таблиця 1 - Технічні характеристики фотосепараторів «Зоркий»

\begin{tabular}{|c|c|c|c|}
\hline \multirow{2}{*}{ Показники } & \multicolumn{3}{|c|}{ Модель } \\
\hline & ZORKIY 3 & ZORKIY 3 & ZZORKIY 3 \\
\hline Продуктивність, т/год & 5 & 10 & 15 \\
\hline Кількість вібролотків, шт & 1 & 2 & 3 \\
\hline Кількість оптичних (ССД) камер, шт & $2 \ldots 4$ & $4 \ldots 8$ & $6 \ldots 12$ \\
\hline Кількість ежекторів, шт & 54 & 108 & 162 \\
\hline Встановлена потужність, кВт & 1,0 & 1,3 & 1,5 \\
\hline \begin{tabular}{|c} 
Габаритні розміри, мм \\
довжина \\
ширина \\
висота
\end{tabular} & $\begin{array}{l}1492 \\
1442 \\
2009\end{array}$ & $\begin{array}{l}1492 \\
1442 \\
2009\end{array}$ & $\begin{array}{l}1492 \\
1442 \\
1009 \\
\end{array}$ \\
\hline
\end{tabular}

На рис. 5 зображені фотосепаратори "Sortex" трьох модифікацій - однолотковий, трилотковий i чотирилотковий, які відрізняються продуктивністю, а продуктивність залежить від числа сепаруючих каналів. Чотири суміжні канали групуються в один блок, а два блоки складають один модуль. В сепараторі СРФ-5,0 зосереджено 7 модулів, один з яких можнавикористовувати у якості контрольного.
Відходи робочих модулів можна спрямувати у контрольний 3 метою отримання більш концентрованих відходів, які видаляють назовні. Основний продукт, вилучений на контрольному модулі, знову подають в робочі разом 3 початковою зернової сумішшю, де відбувається звичайний технологічний процес. Кожні двадцять хвилин відбувається автоматичний контроль якості роботи каналів. Конструкція сепаратора передбачає можливість регулювання продуктивності і рівня стандартного (еталонного) кольору.

Досвід застосування оптичного сепарування за ознакою кольору свідчить про доцільність і перспективність більш широкого впровадження цього напряму на підприємствах галузі. 
Таблиця 2 - Технічна характеристика фотоелектронного сепаратора СРФ-5,0

\begin{tabular}{|c|c|}
\hline Показники & СРФ-5,0 \\
\hline П Продуктивність, $m / 2 о \partial$ & до 5 \\
\hline $\begin{array}{l}\text { Технологічна ефективність, \% } \\
\text { по очищенню основного продукту } \\
\text { (не менше) } \\
\text { по остаточному вмісту кольорових } \\
\text { домішок (не більше) } \\
\text { по вмісту основного зерна у відходах } \\
\text { робочих модулів } \\
\text { (не більше) }\end{array}$ & 95 \\
\hline Число модулів, $u m$ & 7 \\
\hline Число каналів, $u m$ & 56 \\
\hline Витрата стисненого повітря, $\mu^{3} / x в$ & $1,5 \ldots 1,8$ \\
\hline Тиск повітря, $M \Pi а$ & 0,6 \\
\hline Встановлена потужність, $\kappa B m$ & 5,0 \\
\hline $\begin{array}{c}\text { Габаритні розміри (без компресора), } м м \\
\text { довжина } \\
\text { ширина } \\
\text { висота } \\
\end{array}$ & $\begin{array}{l}2100 \\
1400 \\
2200 \\
\end{array}$ \\
\hline Maca, $\kappa 2$ & 850 \\
\hline
\end{tabular}

Фотоелектричні сепаратори можуть замістити деякі традиційні зерноочисні машини - трієри кукіле- і вівсюговідбірники, зерноконцентратори, а також деякі сепаратори основних продуктів лущення круп'яного зерна і контрольні сепаратори для крупи. Це може призвести до оптимізації технологічних процесів і потокових ліній для їх реалізації, а також до підвищення конкурентоспроможності виробленої продукції на внутрішньому і зовнішньому ринках.

Підвищення майже до 99\% ступеня очищення зерна, підготовленого до переробки, сприятиме підвищенню на $3 . .5 \%$ виходу борошна високих сортів і якості круп'яної продукції.

Саме тому оптичне сепарування протягом останніх десятиріч набуло значної популярності у Японії, Китаї, Америці і у багатьох країнах Свропи.

\section{ЛІТЕРАТУРА}

1. Глебов Л.А., Демский А.Б., Веденьев В.Ф. и др. Технологическое оборудование предприятий отрясли. Зерноперерабатываюшие предприятия. - М.: Де Ли принт, 2006. - 816 c.

2. http://elib.altstu.ru/elib/books/Files/va1999_2/pages/45/pap_ 45.html

3. http://agrtek.ru/8B-sortex/

4. http://alta.ua/fotoelektronnyiy-separator-zorkiy-p3

\section{L.S. SOLDATENKO, PhD Tech. Sciences, Ass. Professor}

Odessa National Academy of Food Technologies

\section{FEATURES OF CONSTRUCTION AND APPLICATION OF PHOTOELECTRONIC EQUIPMENT FOR SEPARATION OF GRAIN AND GRAIN PRODUCTS INTO THE FRACTIONS BASED ON COLOR}

\section{Abstract}

The high performance LED optical system design and light control technology ensure maintenance free and reduce $35 \%$ of energy consumption.

The new high-frequency solenoid valve exclusive to color sorter with ultra-low air consumption ensures optimized carryover ratio and high sorting accuracy. It features perfect self-recovery system, low maintenance cost and long lifetime above 10 billion times. The material sorting can be captured dynamically at very high speed as well as analyzed and showed. It realizes truly visualization.

The global leading infrared technology can easily recognize impurities like glass, stones, etc.

The international top-level cloud processing system with incomparable arithmetic capability and perfect program design create a new era of large data. Global initiative cloud and spectrum analysis technologies are adopted.

The internet of things technology adopted initiatively all over the world enable to operate and monitor machine on line as well as service machine on line by manufacturer.

Global initiative operation by clicking one button realizes fully automatic sorting without need of professional.

Global initiative cloud technology camera can deeply recognize tiny impurities. It shows perfect HD scanning, accurate identification and high computing.

Key words: photoelectronic separator, optical separation, color separation, optical system, optical sorting, inspection system, ejector extraction of impurities, photoelectronic separators of the «Zorky» series, «Sortex» photoelectric separators, photo-electronic separator SRF-5,0.

\section{REFERENCES}

1. Glebov L.A., Demskiy A.B., Veden'yev V.F. $i$ dr. Tekhnologicheskoye oborudovaniye predpriyatiy otryasli. Zernopererabatyvayushchiye predpriyatiya. - M.: De Li print, 2006. - 816 s.

2. http://elib.altstu.ru/elib/books/Files/va1999_2/pages/45/pap_45.html

3. http://agrtek.ru/8B-sortex/

4. 4. http://alta.ua/fotoelektronnyiy-separator-zorkiy-p3

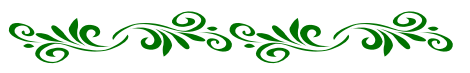

